\title{
The Analysis of Ease of Use, Trust, and Website Quality towards Purchasing Decision in Lazada.co.id
}

\author{
Dadang Suhardi \\ Universitas Kuningan \\ dadang_suhardi@ymail.com \\ Nuryanti Taufik \\ Universitas Galuh Ciamis \\ nuryanti.wibawa@gmail.com
}

\begin{abstract}
This research aims to find out the impact of ease of use, trust, website quality towards purchasing decision in online trading site "Lazada.co.id". The quantitative research is conducted through the implementation of survey. The data collection techniques used in this study with a questionnaire method is distributed to respondents in Ciamis District who had transaction in Lazada.co.id. The number of the sample gained in this research is the population of Ciamis district with the coverage of 100 respondents. The sampling technique used is non-probability sampling with purposive sampling method. The analysis tool applied in this research is by the use of simple linear Regression and multiple linear regression with SPSS 23. The result of the research indicates that the ease of use, trust, and website quality influenced positive and significance towards purchasing decision partially and simultaneously. In this research, website quality gives stronger influence towards purchasing decision comparing with ease of use and trust.
\end{abstract}

Keywords: purchasing decision, trust, ease of use, and website quality

JEL Classification: C83, L81, M31

\section{INTRODUCTION}

In one latest decade, the
growth of technology and information is in advanced line. The growth can be felt from various aspects starting from communication, electronic, transportation, and another field. The growth influences directly and non-directly towards the style of society. One of the striking points from the growth of technology and information to many internet users as stated on data from Komifindo.go.id direct that as a whole, the internet users in the entire world are projected up to 3 million people in 2015. Three years later in 2018, the member of 3.6 million people in this earth will access internet at least once in a month.

Indonesia Internet Service Users Association / Asosiasi Pengguna Jasa Internet Indonesia (APJII) 
exposes survey product about penetration and Indonesia internet user behavior in 2017. The secretary General of APJII, Henri Kasyfy Soemartono states that the number of Indonesia internet users comes to 143.26 million in 2017. The growth of internet users pushes a big potency to create online shopping with the total of internet users as the number of online buyers through e-commerce in Indonesia achieves 24.7 million people based on waresocial data in 2017. In line with the above statement , the opportunity to run on online business opens widely for businessman in Indonesia.

One of the online shopping site in Indonesia that is growing fast is Lazada Indonesia. Lazada.co.id is trading site daring which offers various products starting from electronic, books, toy and baby outfit, health equipment, beauty product, household tools, traveling equipment and sport. Lazada Indonesia was built in 2012 as a part of Lazada group and operates in southeast Asia. Up to 2014, Lazada group has operated in Singapore, Malaysia, Indonesia, Vietnam, Thailand, Philippines and Singapore is as the center of their office. Lazada group itself is as one of German internet branch companies named Rocket Internet. Rocket Internet is a success daring incubator company that creates innovative online companies in every part of the world.

Based on the survey on Top Brand Awards Site, Lazada co.id enables to get $19.9 \%$ market share online shopping site in 2016 but the amount decreases up to $18.0 \%$ in 2017. The increase of buyers in online shopping site in 2017 does not mean the market share also increases, and in fact, the decrease of $1.9 \%$ market share occurs. In the phenomenon of online shopping, some considerations that can be the factor in doing purchasing decision is, one of them, easy of use.

Davis (1989) defines "easy of use as a level where someone believes that one technology can be easily used", and in this case, an online shopping site must be able to give easy of use to users in the level where a user believes that technology or system can be used easily and out of problem.

Then, the trust of purchaser towards shopping online is believed to have an important role to influence decision of purchasing. "If an online shopping site is getting popular then the level of public trust level towards the site is getting high (Morgan and Hunt, 1994). The other factor that supports customer in doing purchasing online is the website quality. A company website must present the company absence in the eye of costumers virtually in order the costumers believe and do online transaction through company website (Sarwono and Prihartono, 2012). Then, in the website quality there is information quality component which is as one factor that influences the decision in purchasing online.

The complete information is urgently required by the purchaser candidate in deciding transaction through online shopping as there is no meeting between buyer and 
seller directly. The information quality is defined as costumers' perception towards information quality about product or service which is provided by a website (Park and Kim, 2003 in Loo, 2011).

The information is benefit and relevance in predicting quality and the use of product or service. To satisfy costumers' needs on information, the information product and service must be up to date in order to help online customers in doing decision, consistency and easy to understand. The product information in online shopping covers information attribute of a product, recommendation to costumers, evaluation report and so on. "The product attribute information is information about product specification which means measurement dimension, color dimension, fabric dimension, technology dimension and basic price of a product" (Gefen, Karahanna, et al., 2003; Gefen and Straubb, 2004)

\section{Research Question}

1. How is the influence of ease of use towards purchasing decision in the Lazada.co.id online site?

2. How is the influence of costumers' trust towards purchasing decision in Lazada.co.id online site?

3. How is the influence of website quality towards purchasing decision in the Lazada.co.id online site?

4. How is the influence of ease of use, trust, and website quality altogether towards purchasing decision in the Lazada.co.id online site?

The aim of the research

From the identified problem as the base of the research above, the aims of the research are:

1. To know ease of use towards the purchasing decision in Lazada.co.id site.

2. To know the influence towards purchasing decision in Lazada.co.id site.

3. To know the influence of website quality towards purchasing decision in Lazada.co.id site.

4. To know the influence of ease of use, trust and website quality altogether towards purchasing decision in Lazada.co.id site.

\section{The Benefit of the Research}

\section{Theoretical Benefit}

Theoretical benefit from the research is as important contribution to wide atmosphere for marketing management study concerning with ease of use, costumers' trust, and website quality in online shopping transaction in order to be a direction to build strategy in increasing service an online shopping site.

\section{Practical benefit}

The result of the research can be a thought of management contribution to online shopping Lazada.co.id site related with the influence ease of use, trust, and website quality towards costumers purchasing decision to their site. The result of the research can be used as a tool for the further research involving with how to build trust to costumers and how to 
prepare complete website quality in the process of online shopping because as a matter of fact that in this globalization era, the online shopping is a trend which keeps growing and beneficial.

\section{LITERATURE REVIEW}

\section{Ease of use}

Davis (1989) defines ease of use as a level where a person believes that a technology can be easily used. Ease of use to individual belief directs that the use of the system does not need much effort. Ease of use is a part of Technology Acceptance Model (TAM). TAM is one of theories that use behavioral theory approach which is used to analyze adoption process of information technology. Juniawati (2014) in her research found that perceived ease of use has strong influence on purchase intention in online shopping, and this it shown by result that ease of use can gave significant influence toward intention to shop online. The indicators of ease of use based on Hardiawan (2013) are as follow: easy to learn, easy to operate the required system, easy to use, flexible in use, time efficiency.

\section{Trust}

Trust is expectation which is held by a person concerning with relying on the person's utterance. The trusted group needs to own high integrity and believable which is associated by quality: Consistency, competency, honest, fair, responsibility, helpful and kind (Morgan and Hunt, 1994). Mowen and Minor (2002:322) define "costumer trust is as the whole knowledge owned by costumers and all conclusion made by costumers about object, attribute and benefit from one product or service. The first consideration made by a buyer when they do purchasing online is that whether they believe to online purchaser in the website. Many results researches direct that trust is the important factor in building commitment between company and costumers. Based on Rosseau et al. (1998) that: "Trust is very important to build and construct long term relationship."

Shen (2008) says that " Trust indicator is more to comfortable feeling when someone does transaction in the purchasing site and he divides indicator of costumer trust in purchasing online into four parts, they are :

1. Safety system

2. Secret system

3. Secret and security guarantee

4. Loss compensation because of security and secret reasons.

\section{Website Quality}

"Website quality has gained great attention from academic and practitioners equally because of its vital role in developing customers' purchase intentions" (Faizan, 2016). Mona et al. (2013) explained that "customer perception about website quality based on features in a website meet with customers' needs and impress of that website". Mona et al. (2013) also explained that dimensions of website quality can be categorized as security, enjoyment, information quality, ease of use, and service quality. 
Hyejong and Niehm (2009: 222) state that researchers divide website quality dimension into five categories: 1). Information that covers content quality, use, completeness, accuracy and relevancy 2). Security covers trust, privacy, and security guarantee. 3) Ease of use covers easy to operate, easy to understand and speed. 4). Comfort covers visual appeal, emotional appeal, attractive and creative design.

\section{Purchasing decision}

Engel et al in Pride and Ferrel (1995) explains that "purchasing behavior is decision process and action of the involved people in buying and using product. Purchasing decision is an individual activity which involves directly in taking decision to do buying from the offered product by the seller. Based on Kotler and Amstrong (2001) that the meaning of purchasing decision is the step in taking process of buyer decision where costumers really buy. Generally, decision is selection from two or more alternative choice (Schiffman and Kanuk, 2000). In other words, alternative choice must be included in making decision. In the contrary, if costumers don't have alternative to choose, this is not categorized as taking decision.

Based on Kotler and Keller (2008: 166-189) that indicators of purchasing decision are as follow:

1. Need

2. Public

3. Benefit

4. Other people behavior

5. Satisfaction

\section{Hypotheses}

Based on the description of background, the framework of thought, then the hypothesis which could be stated in this research is:

1. There is influence of ease of use towards purchasing decision in online shopping Lazada.co.id

2. There is influence of trust towards purchasing decision in online shopping Lazada.co.id

3. There is influence of website quality towards purchasing decision in online shopping Lazada.co.id

4. There is influence of ease of use, trust, and website quality altogether towards purchasing decision in online shopping Lazada.co.id

Figure 1. Research Model

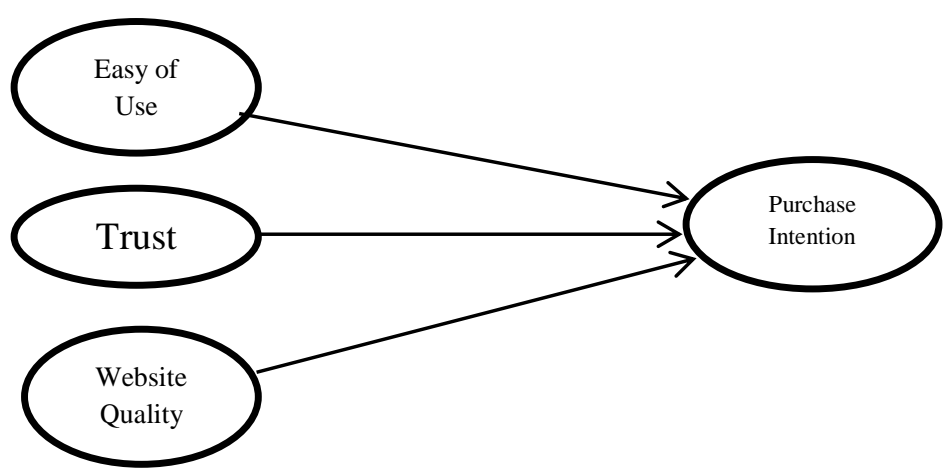




\section{METHOD, DATA AND ANALYSIS Research method}

The research method used in this research is quantitative with explanation method and by survey approach. Explanation method explains a sample generalization towards population or explains different relationship or influence a variable with another variable. Based on that, the explanation research uses sample and hypothesis. The research type is chosen because the researchers will measure relationship and influence between one variable with the other variable. The explanation format by Bungin (2001:15) aims at describing a generalization or describing relationship between one variable with the other variable. This research uses "taking sample with Slovin method and cluster sampling". Slovin method is used to get amount of total sample when cluster sampling method is used to determine the amount of sample taken from every cluster in the research population. The amount of cluster in this research is the number of environment in Ciamis district. To know how big the representative sample, the Slovin formula in Husen (2005: 108) is used.

$$
n=\frac{N}{1+\left(N \cdot e^{2}\right)}
$$

Based on the formula, the sample size can be counted as follow:

$$
n=\frac{N}{1+\left(N \cdot e^{2}\right)}
$$

$n=\frac{17.312}{1+\left\{17.312 \cdot\left(0,1^{2}\right)\right\}}$

$n=\frac{17.312}{174,12}$

$\mathrm{n}=99.425$ is counted into 100 respondents.

In this research, the researchers use Likert scale in questionnaire. Likert scale is used to measure attitude, opinion and perception of someone or group of people about social phenomenon (Sugiyono, 2008: 93). The method of analysis data used in this research is simple linear regression to analyze relationship between each of free variables and bound variable and double linear regression analysis to analyze relationship between free variable altogether with bound variable. The analysis tool used is SPSS 23. 
Data Analysis

Simple linear regression analysis

Table 1. The examination finding on simple regression analysis

\begin{tabular}{|c|c|c|c|c|}
\hline No & Variable name & $\begin{array}{c}\text { The score of } \\
\text { correlation } \\
\text { analysis (R) }\end{array}$ & $\begin{array}{c}\text { The score of } \\
\text { determination } \\
\text { coefficient (R2 in } \\
\text { percentage) }\end{array}$ & $\begin{array}{c}\text { The result of } \\
\text { T test }\end{array}$ \\
\hline 1. & Ease of use & 0.946 & $89.3 \%$ & 28.834 \\
\hline 3. & Trust & 0.787 & $61.9 \%$ & 12.629 \\
\hline 2. & Website quality & 0.945 & $89.4 \%$ & 28.725 \\
\hline
\end{tabular}

Table 2. Hypothesis Examination of each independent variable

\begin{tabular}{|l|l|l|l|}
\hline No & The name of variable & $\begin{array}{c}\text { The comparison between } \mathrm{t} \\
\text { count and score of } \mathrm{t} \text { table }\end{array}$ & \multicolumn{1}{c|}{ Conclusion } \\
\hline 1 & Ease of use & $\mathrm{t}$ count $28.834>\mathrm{t}$ table 1.985 & $\mathrm{H} 1$ is accepted \\
\hline 2. & Trust & t count $12.629>\mathrm{t}$ table 1.985 & $\mathrm{H} 2$ is accepted \\
\hline 3. & Website quality & $\mathrm{t}$ count $28.725>\mathrm{t}$ table 1.985 & $\mathrm{H} 3$ is accepted \\
\hline
\end{tabular}

Multiple Regression Analysis

Based on the result of multiple linear regression analysis, the agreement gained is:

$\mathrm{Y}=19.392+0.53 \times 1+0.96 \times 2+$ $1.012 \times 3$

With the result:

Correlation score $=0.864$

Determination Coefficient score $=76.4 \%$

Score of $F$ count $=58.769$

Score of $\mathrm{F}$ table $=2.70$

$F$ count $58.769>F$ table 2.70 means the fourth hypothesis is accepted.

\section{RESULT AND DISCUSSION}

The influence of ease of use towards purchasing decision

The result of the research directs that variable ease of use influences positively towards the variable of purchasing decision respondent in Lazada.co.id site. The result is in line with some previous researches such as Davis (1989);
Venkatesh and Davis (2000); Pikkarainen, et al. (2004) which state that ease of use is a main factor that influences towards the use of online shopping. Based on the above statement, it can be said that ease of use variable influences costumer decision to do online transaction.

Based on the result from the questionnaire in the research, respondents mainly answer that they get ease of use and time efficiency when they do purchasing transaction in Lazada.co.id site. This is because they can access Lazada.co.id through their cellular phone. To process product selection, seek information on products, compare product price from one shop to another shop, costumers only do clicking to the menu in Lazada.co.id application. This ease of use can finally make costumers to decide transaction in Lazada.co.id. Besides, 
time coefficient has more value which is also owned by general shopping online system and especially in Lazada.co.id site. Costumer can easily access Lazada.co.id where and when they are. Transaction process is easier by providing system of mobile banking payment, so the customers, in the time aspect, can reduce their time without arriving to the real shop. Online shopping can be the accurate solution to those who are very busy and economize time in shopping.

\section{The influence of trust towards purchasing decision}

The result of the research states that trust variable influences towards respondent's purchasing decision variable in Lazada.co.id site and this is based on some previous researches. Some previous researches concerning with trust (Gefen, Karahanna, et al., 2003; Gefen and Straub, 2003) state the result that trust influences positively towards website purchasing decision. Based on the questionnaire result of this research, respondent mainly answer that they are comfortable to do purchasing transaction in Lazada.co.id site. This is because when costumers do purchasing in Lazada.co.id, the money they transfer does not directly enter to the seller account but the money is saved in the account together with Lazada.co.id. After the ordered product is sent by the seller, the next step is the costumer waits the product to their hand. When the product is on the costumers' hand safely and the product is also similar with what has been ordered, then the money will be transferred by Lazada.co.id to the seller. The kind of payment system makes costumers trust to do purchasing transaction in Lazada.co.id in minimizing trickery. Although most of the respondents feel comfortable and trust to the transaction in Lazada.co.id site, in some cases, some respondents don't believe Lazada.co.id in their answer because they experienced trickery. This is because they don't do payment transaction through Lazada.co.id service. They do transaction out of Lazada.co.id and they only see the provided advertisement and then do transaction with the seller directly. This can create an opportunity to trickery action because the money in processing the ordered product is not saved in Lazada.co.id but goes directly to the seller account and it creates higher trickery risk.

\section{The influence of website quality} towards purchasing decision

The result of the research states that website quality of Lazada.co.id is able to attract customers in doing transaction. Based on the variable of recapitulation indicator of website quality in Lazada.co.id site, visual appeal indicator is the indicator that mostly gains score. Based on the respondents, visual appearance in Lazada.co.id site is very attractive. By having profile and various option menu, costumer can do searching product with various searching filters that facilitate them in gaining product they need such as price filter, kind of product brand, and 
also the color of the chosen product. The other service in the website that makes costumer really like the website is because of the testimony from the previous costumer about product, so they can refer to their testimony as their recommendation in the process of choosing product. Besides, "flash sale" promotion that occurs only few hours with bewitching discount and the amount of limited product, Lazada.co.id is getting close to costumer by its program and this implies to the increase of costumer's need to do transaction in Lazada.co.id

\section{CONCLUSION}

Based on the result of the research and discussion, the writers take conclusions as follow:

1. Ease of use variable influences positively towards purchasing decision variable by gaining $t$ count $(28.834)$ $>t$ table (1.985) with the variable influence of ease of use towards purchasing decision 89.3 percent. This research proves that costumers trust is able to be one of influencing variables towards costumers purchasing decision in Lazada.co.id site.

2. Trust variable influences positively towards purchasing decision variable by gaining tcount (12.629) $>$ ttable (1.985) with the influence of trust variable towards purchasing decision 61.9 percent. This research proves that costumer trust is able to be one of the variables that influences to the costumer's purchasing decision in Lazada.co.id site.

3. Website quality variable influences positively towards purchasing decision variable by gaining tcount (28.725) $>$ ttable (1.985) with the influence of website quality towards purchasing decision 89.4 percent. This research proves that website quality is able to be one of the variables that influences to purchasing decision in Lazada.co.id site.

4. Based on the partial examination, ease of use variable, trust variable and website quality are able to give influence positively and significantly towards purchasing decision in Lazada.co.id site. By examining simultaneously and by the use of $F$ test, Fcount (58.769) >Ftable (2.70) is gained. This means if these are examined together, both of the variables influence positively and significantly with the 74.6 influence.

\section{IMPLICATION/ LIMITATION AND SUGGESTION}

Lazada.co.id must be able to keep giving ease of use to the costumers because as based on the result of the research, variable ease of use is able to influence people positively towards purchasing decision. 
Lazada.co.id must keep giving education to market on how to do transaction in their site in order to create costumers higher access and do real transaction in their site.

Lazada.co.id must be able to keep increasing trust to costumers to be brave to do transaction in their site, as based on the research, the variable of trust is able to influence positively to purchasing decision. Lazada.co.id can keep increasing security site in order not to find costumer deception and beside, Lazada.co.id must give comprehension to all the costumers who are willing to do transaction to do transaction only in Lazada.co.id - not in other site.

Website quality in Lazada.co.id site has been able to give positively to purchasing decision but Lazada.co.id must keep in touch with development in their website in order to follow costumers' need and desire continuously and also enable to do challenging with another online transaction site.

The suggestion for the further research is to explore independent variable that is able to influence online purchasing decision and also to add dependent variable instead of purchasing decision, e.g. repeated purchase and loyalty. The target of research subject and location are also needed to examine deeply the unused variable in this research.

\section{REFERENCES}

APJII. (2017). Hasil Survei Penetrasi dan Perilaku Pengguna Internet Indonesia 2017. Retrieved from https://apjii.or.id/content/read /39/342/Hasil-Survei-Penetrasidan-Perilaku-Pengguna-InternetIndonesia-2017.

Bungin, B. (2001). Metodologi Penelitian Sosial. Surabaya: Universitas Airlangga.

Davis, F.D. (1989). Perceived Usefulness, Perceived Ease of Use and User Acceptance of Information Technology. MIS Quarterly, 13(3), 319-340.

Faizan, A. (2016). Hotel website quality, perceived flow, customer satisfaction and purchase intention. Journal of Hospitality and Tourism Technology, 7(2), 213-228.

Gefen, D., Karahanna, E., \& Straub, D.W. (2003). Trust and TAM in online shopping: An integrated model. MIS Quarterly, 27(1), 5190.

Gefen, D. \& Straubb, D.W. (2004). Consumer Trust in B2C eCommerce and The Importance of Social Presence: Experiments in e-Products and e-Services. Omega, 32(6), 407 - 424.

Husein, U. (2005). Riset pemasaran dan Perilaku Konsumen, Jakarta: PT Gramedia Pustaka Utama.

Hardiawan, A.C. (2013). Pengaruh Kepercayaan, Kemudahan, dan Kualitas informasi Terhadap Keputusan Pembelian Secara online pada Toko Bagus. (Undergraduate Thesis, Fakultas Ekonomi dan Bisnis Universitas Diponegoro, Semarang). 
Hyejeong, K \& Linda S.N. (2009). The Impact of Website Quality on Information Quality, Value, and Loyalty Intentions in Apparel Retailing. Journal of Interactive Marketing, 23 (3), 221-233.

Juniawati. (2014). Influence of Perceived Usefulness, Ease of Use, Risk on Attitude and Intention to Shop Online. European Journal of Business and Management, 6(27), 218228.

Kominfo (2017). Jumlah Pengguna Internet di Indonesia. Retrieved from

https://kominfo.go.id/content/ detail/4286/pengguna-internetindonesia-nomor-enamdunia/0/sorotan_media

Kotler, P \& Kevin, L.K. (2008). Manajemen Pemasaran Jilid 1. Jakarta: Erlangga.

Kotler, P \& Gregory, A. (2001). Dasar-Dasar Pemasaran Edisi Indonesi Jilid II. Jakarta: Prenhallindo.

Loo, R. (2011). Faktor-Faktor yang Mempengaruhi Kepuasan, Kepercayaan, dan Kesetiaan Konsumen Dalam Membeli Produk di Website Online Kaskus. Jurnal Ilmiah Mahasiswa Manajemen, 1(3).

Mona, et al. (2013). Linking trust, perceived website quality, privacy protection, gender and online purchase intentions. IOSR Journal of Business and Management (IOSR-JBM), 13(4), 63-72.
Morgan, R.M. \& Hunt, S.D. (1994). The commitment-trust theory of relationship marketing, Journal of Marketing, 58(3), 20-38.

Mowen, J. C \& Minor, M. (2002). Perilaku Konsumen Edisi Kelima Jilid 1. Jakarta: PT Penerbit Erlangga.

Pride, W. M \& O. C. Ferrel. (1995). Pemasaran Teori dan Praktek Sehari-hari. Jakarta: Penerbit Binarupa Aksara.

Rousseau, D.M. (1998). The 'problem' of the psychological contract considered. Journal of Organizational Behavior. 19, 665-671.

Sarwono, J. \& Prihartono, K. (2012). Perdagangan Online: Cara bisnis di Internet. Jakarta: Elex Media Komputindo.

Schiffman \& Lazar, K. (2000). Costumer behaviour. Internasional New Jersey: Prentice Hall.

Sugiyono. (2008). Metode Penelitian Bisnis. Bandung: Alfabeta.

Topbrand Award. (2016). "Top Brand Index". Retrieved from http://www.topbrandaward.com/top-brandsurvey/survey result/top_brand_index_2016_fa se_2.

Topbrand Award. (2017). “Top Brand Index". Retrieved from http://www.topbrandaward.com/top-brandsurvey/surveyresult/top_brand_index_2017_fa se_2. 